\title{
Private Higher Education in Africa: Old Realities and Emerging Trends
}

\author{
Wondwosen Tamrat
}

\begin{abstract}
The growth of private higher education in Africa has been driven by factors such as burgeoning demand that could not be met by the public sector and policy influences as Structural Adjustment Programmes that promoted privatisation in the I980s and beyond. In the past three decades, the continent's private higher education institutions have exhibited different growth trajectories. Variations are also evident in their policies and the quality of their offerings. However, the variation and incremental growth of this sector is not adequately captured in the extant literature. This article investigates Africa's private higher education sector based on past and emerging realities and argues that the sector exhibits nuances that have not received sufficient attention due to excessive stereotyping of PHE in Africa and elsewhere. Understanding these differences, which are sometimes described as 'exceptions', is a prerequisite for developing a comprehensive conceptualisation of current tapestries and future trends. The article begins by examining the major features of global private higher education and proceeds to Africa with its major focus on emerging trends within the continent.
\end{abstract}

Key Words: higher education, private higher education, private colleges, African higher education

Des facteurs comme la demande croissante qui ne pouvait être absorbée par le secteur public et les influences politiques des Programmes d'Ajustement Structurel qui ont promu la privatisation pendant les années 80 et après sont à l'origine de la croissance de l'enseignement supérieur privé en Afrique. Pendant les trois dernières décennies, les institutions privées d'enseignement supérieur ont présenté différentes trajectoires de

ABOUt THE AUtHOR: WONDWOSEN TAMRAT is an associate professor and the founding president of St. Mary's University, Ethiopia. E-mail: wondwosentamrat@gmail.com 
croissance. Des différences sont aussi observables quant à leurs politiques et à la qualité de leur offre. Cependant, la variété et la croissance progressive de ce secteur ne sont pas correctement reflétées dans la littérature existante. Cet article examine le secteur de l'enseignement supérieur privé en Afrique à partir de réalités anciennes et nouvelles et soutient que les nuances de ce secteur n'ont pas reçu une attention suffisante à cause des stéréotypes excessifs auxquels fait face l'enseignement supérieur privé en Afrique et ailleurs. Comprendre ces différences, qui sont parfois catégorisées comme des exceptions, est un prérequis pour pouvoir conceptualiser de manière compréhensive le contexte actuel et les tendances futures. Cet article commence par analyser les caractéristiques principales de l'enseignement privé mondial avant de se focaliser sur l'Afrique avec une attention toute particulière pour les tendances émergentes sur le continent.

\section{Understanding Private Higher Education: Conceptual Clarifications}

Defining private higher education (PHE) has always been a challenging task due to the fragility of its conceptual moorings. It can have different connotations depending on the context in which it is discussed. The preferred route has focused on understanding the distinguishing characteristics of private institutions in contrast to their public counterparts, the major areas of comparison being the dimensions of funding, governance, function and ownership.

In terms of funding, private sources are the major means of funding for PHEIs especially for-profit institutions which are self-financing, mainly through student fees. However, there are exceptions to this rule. Indian PHEIs receive financial support from the government on condition that they are affiliated to public institutions (Altbach, I998).In the Netherlands and Belgium, PHEIs are also funded by the government (Geiger, 1987).

Turning to their management locus, PHEIs are primarily accountable to their founding institution/s or individuals and internal control is held by institutions themselves. Since they have a somewhat loose relationship with the state, they are relatively free from government and political influence (Bernasconi, 2004). However, in South Korea the government determines PHEIs' class sizes and staff salaries, suggesting excessive government interference in institutional matters (Altbach, I998).

Although not always applicable, PHEIs are also distinguished from their public counterparts in terms of the type of training they offer. They favour teaching programmes that do not require heavy investment in infrastructure and are flexible in offering programmes that suit their clientele. As a result, these institutions mainly focus on specific areas such as Business, IT, and Law. 
Ownership of private institutions can assume a variety of patterns. They could be owned by individuals, non-governmental organisations (NGOs), non-profit organisations (NPOs) and/or religious entities (James, I989). As business organisations, for-profit PHEIs could also be owned by proprietary arrangements such as sole ownership, private limited companies and/or share holdings.

Another widely used classification for understanding the nature of PHEIs has been their profit motive. These institutions can be grouped into for-profit or not-for-profit/ non-profit. For-profit PHEIs which are on the increase globally exist in different forms including those that achieve corporate and global stature with the possibility of being listed as companies (Levy, 2003). The non-profit category mainly embodies institutions owned by religious groups and non-religious institutions that claim not to have a profit focus. However, this classification could be tricky as even in countries where constitutional or other laws do not favour of a profit motive or are silent on this issue, PHEIs may pursue profits through disguised or indirect means (James, I989; Levy, 2003).

\section{The Global Surge and Patterns of PHE}

The proliferation of PHEIs across most parts of the world is widely believed to have begun in the I990s. However, the first wave of PHE growth occurred much earlier with the creation of religious institutions that accounted for most of the world's PHEIs until the mid-twentieth century (Levy, 2002, 2003) and exist to this day, most of them Christian (Altbach, 2005).

The inception and growth of PHEIs in different regions of the world in the past three decades have been marked by the emergence of three major structural types of higher education systems: mass private with a restricted public sector presence; parallel public and private sectors; and a comprehensive public and peripheral private sector (Geiger, I987).

In mass private with restricted public sector systems, PHEIs assume significant dominance over the public sector. These are mainly located in Asia and the Pacific, especially in Japan, South Korea, Taiwan, the Philippines, and Indonesia where students in PHEIs could exceed 75 percent of total higher education enrollment. Some countries in Latin America exhibit similar trends. For example, two-thirds of students in Brazil and Colombia are enrolled in the PHE sector (Sayed, 200I). In Chile, the private sector represents 93 percent of institutions and 7I percent of enrolments, making it among the world's leaders in private provision of higher education (Bernasconi, 2003). Most of these countries have consciously promoted the private sector through diverting public money intended for higher education to other sectors or levels of education.

The driving force for systems that accommodate parallel public and 
private sectors is the need for a significant degree of cultural pluralism within a non-hierarchical system which results in full state funding for private universities (Geiger, 1987). The private and public sectors may grow side by side as the significance of both is acknowledged. Welfare states such as Belgium and the Netherlands are considered as typical examples in this category (ibid).

On the other hand, systems with comprehensive public and peripheral private sectors regard the PHE sector as an appendix to the existing dominant public system. The public sector fulfills most of the need for higher education and hence the private sector may be denied attention for economic or political reasons and assumes a limited and peripheral role. Countries in Western Europe are good examples of this type of system (Altbach, I998; Bjarnason et al., 2009). Sub-Saharan Africa is another example where the growth of the PHE sector is limited despite policy changes in government financing of public institutions.

It is important to note that classification of a given country in any of the aforementioned categories is not static and can change over time, subject to the social and political context.

\section{Factors Influencing the Growth of Global Private Higher Education}

The growth patterns of PHE in different parts of the world have been driven by a variety of factors that are mainly related to massive demand for higher education and the deregulation of the sector that led to increased privatisation.

In many parts of the world, public higher education institutions have failed to meet local demand, opening the way for the private sector. The startling growth of PHEIs in many developing countries in the post-communist period is often associated with this factor (Kruss, 2003; Levy, 2003). For instance, I.5 million students apply for the matriculation examination in Nigeria each year but universities can only accommodate 350,000 (Olayia, 20I5). In Kenya, 60 percent of high school leavers do not secure a place at public or private higher education institutions (Banya, 200I; Oanda, Chege, and Wesonga, 2008). This situation is identified in the literature as 'the demand for more education' implying the absorption of excess needs, which public providers have not been able to satisfy.

In contexts where the state is able to satisfy demand, the needs of groups with particular demands could be met by private institutions (Kruss, 2003). The growth of Catholic universities in Latin America and religious PHEIs in Africa is explained by 'differentiated demand' (James, I989; Thaver, 2003). In Russia and East and Central Europe PHE emerged to address demand for academic programmes that were not available under communist rule (Kodin, I996). 
The growth of private education could also be a response to deficiencies or the failure of public institutions in various areas one of which is the quality of teaching (Atchoarena and Esquieu, 2002). Private institutions respond to demand from the elite for 'quality' education (James, I989; Levy, 2002; Kruss, 2003). PHEIs in the US are classic examples. One of the major reasons for the growth of the second wave of PHEIs in Latin America was "a reaction to the perceived 'massification' or decline in quality of public higher education" (Levy, 2002, p. 6). The rise of the PHE sector in South Africa in the mid-I990s is partly ascribed to demand from the predominantly white population for 'better education' (Thaver, 2003).

In terms of policy, privatisation has significantly contributed to the proliferation of PHEIs. Levy (2002) contends that one of the major reasons for the unanticipated growth of PHE worldwide is the adoption of neoliberal policies that seek to restrict the role of the state. International agencies such as the World Bank (WB) have exerted considerable pressure for the market to play a more prominent role in providing educational services and have prescribed privatisation as a means to meet demand for access to postsecondary education (Altbach, I998). Arms of the World Bank (WB) such as the International Financial Corporation support private investment in education at secondary and tertiary levels with the aim of diverting public resources to access to better quality education (Sayed, 200I). The World Trade Organization's (WTO) General Agreement on Trade in Services (GATS) has also been influential in promoting the marketing of education at various levels across countries. UNESCO holds a similar, but more restrained, position advancing the claim that public funds alone will not sustain a viable and differentiated higher education system (Kent, I995).

The structural adjustment programmes (SAPs) promoted by the WB and other international agencies also explain the growth of PHE. For instance, under the guidance of the WB and International Monetary Fund (IMF), Uganda underwent seven structural adjustments in the I980s that included the removal of subsidies from higher education. This triggered the growth of private provision of schooling at all levels (Tsevi, 20I5; Ochwa-Echel, 20I6). In similar vein, in advancing credit assistance to Kenya, the WB prevailed on the government to restrict the growth of enrollment in public universities, resulting in the growth of the private sector (Abagi, 2006).

Transnational education, which is a major feature of recent developments in many higher education systems, is also contributing to the creation of new PHEIs and/or the diversification of programmes in existing institutions. Many Western institutions that have been constrained by financial austerity are making aggressive moves to capture the higher education market in the developing world. Such plans have been particularly successful in countries where overseas higher education is perceived to 
offer advantages such as employment and mobility opportunities (Sayed, 200I; Lee, 2003).

\section{PHE Presence in Africa: Patterns and Trends}

Compared to other regions, knowledge of Africa's PHEIs is "less reliable, scarcer and more scattered" (Levy, 2009, p.I3). Only five percent of the entries in an International Bibliography on Private Higher Education relate to Africa and mainly refer to South Africa (Maldonado-Maldonado et al., 2004). Hence, accurately estimating the size of the private sector on the continent remains a challenge.

The extant literature shows that, although tertiary education in general and private education in particular has expanded considerably in developing regions since the I970s (Levy, 2013), it remains very small, especially in sub-Saharan Africa where the gross enrollment ratio is still limited. This is mainly because African higher education has been dominated by public universities that were regarded as a symbol of self-reliance in the post-independence period (Sayed, 200I), leaving little room for PHEIs until the I990s. Growing demand for higher education, privatisation and continental developments over the past three decades account for the growth of PHE that has become one of the fastest growing segments of the higher education sector. While the number of public universities doubled from about Ioo to nearly 200 from I990 to 2007, the number of PHEIs exploded from two dozen to an estimated 468 (World Bank, 2009). While this figure looks an underestimation, it must have significantly changed over the last decade. In Ethiopia alone, there are now more than I20 PHEIs operating. The overall pattern indicates that the number of private institutions is much higher than public institutions. Nonetheless, African private higher education institutions only accommodate 20 percent of total higher education enrollment, below the global average of 3I percent (Levy, 2013).

Variations in the growth of PHEIs across individual African countries are also instructive. The East African region is credited with the introduction of PHE to the continent, with Kenya identified as the first country to take the initiative followed by countries such as Benin, Senegal, Tanzania, Uganda, Ghana, Mozambique, and Cameroon (Varghese, 2006). Ethiopia joined this group in the late I990s. With IIo PHEIs and more than I00,000 students enrolled in undergraduate and post-graduate degree programmes, it now seems to lead the way.

In terms of type of private institutions, there has been a proliferation of for-profit institutions, although religious ones still dominate. In Kenya, Nigeria, Tanzania and Zimbabwe the majority of PHEIs are owned by religious bodies (Varghese, 2006; Ishengoma, 2010). Although this is also the case in Senegal, the for-profit sector is gaining ground (Ndiaye, 2006). 
Ghana accommodates both for-profit and not-for-profit institutions while most PHEIs in Mozambique are owned by business organisations (Effah, 2006; Tsevi, 2015; Langa and Zavale, 2015). Private institutions in Egypt, South Africa and Ethiopia are predominantly for-profit (Levy, 2003; Tamrat, 2008; Barsoum, 20I4). For-profit PHEIs in most parts of Africa are owned by individual proprietors, corporate and foreign organisations and agencies that collaborate with local institutions (Varghese, 2006).

The various programmes at African PHEIs are mainly provided at three types of institutions: private universities, private colleges, and non-university institutions or professional schools (Thaver, 2003; Varghese, 2006). The mix in a given country is determined by a variety of factors including the legislative framework, the market niche for programmes offered and PHEIs' capacity to meet programme demand at a given level. In some contexts, institutions could run specific programmes from the list of professional trainings, vocational courses, and undergraduate and postgraduate programmes available. There could also be instances where a single provider offers various types of programmes under one roof.

\section{Past Realities and Views on PHEls in Africa}

As noted earlier, over the past three decades, there has been a proliferation of PHEIs in almost every part of the world. The surprise element in their appearance and roles (cf. Levy, 2002) no longer seems a novel point of discussion. The initial debate as to whether such institutions should be allowed to exist in light of their potential impact on the public sector seems to be no longer tenable. Today, the debate has shifted to the role these institutions could play in advancing the sector as a whole. PHEIs are slowly but surely moving from the periphery to the mainstream in the higher education sector in many countries. Despite this, there is a paucity of empirical research on the various aspects and manifestations of this sector. In many respects, the deficiencies Levy noted a decade ago persist:

Private higher education remains largely a niche field for scholarship. Mainstream higher education literature has shown academia's common sluggishness in identifying and analyzing fast-changing phenomena.... Ad hoc impressions and heated and poorly informed polemics usually predominate while vital and multiple policy issues are at stake in country after country (2005, p. I).

While such deficiencies are pronounced in Africa, they are not peculiar to this continent, the only exception being the US (Levy, 2002). While information on the profile and various aspects of the public education system in any given country is available, work on PHE is in most cases limited, patchy, and anecdotal.

A major exception is the pioneering work of Daniel Levy and his group 
under the Program for Research on Private Higher Education (PROPHE) at the University of Albany, SUNY. Since its inception in 2000 , the PROPHE has built a sizable database on the PHE sector worldwide through a network of scholars in 20 countries (Levy, 2005). The Center for International Higher Education, Lynch School of Education, Boston College has also built research on PHE and has liaised with the PROPHE (cf Altbach, I999). In similar vein, the International Financial Corporation, the private sector arm of the WB has held annual research events since 2006 exclusively devoted to private education where research papers and country case studies are presented.

In the I990s, the Human Sciences Research Council and the Education Policy Unit at the University of the Western Cape took the initiative to develop a national information base on PHEIs in South Africa. The current status of this project is not known. Furthermore, St Mary's University in Ethiopia has hosted annual conferences with an exclusive focus on PHE since 2003. In addition to posting this information on its website, the University has recently joined hands with the Association of African Universities, African Union and IICBA/UNESCO to transform the conference into a continental undertaking that builds a broader research base and disseminates studies on this subject.

While the poor knowledge base on PHE can be explained partly by researchers' focus on the public sector, PHEIs have a poor record in researching their own provisions, documenting their data and/or underreporting or exaggerating information about their performance and the sector at large. For instance, more than 30 percent of Ethiopian PHEIs do not provide annual data to the Ministry of Education as required (MoE, 20I5). In such an environment, positive assessments of a sector that has always been viewed with suspicion and mistrust will not be forthcoming (Giesecke, 2006). There is thus "a special need to produce much more knowledge and understanding about the private sector in higher education" (Varghese, 2012, p. 228).

As noted earlier, research on the PHE sector also suffers from static images and stereotypes of poor quality, low academic standards, limited programmes that focus on inexpensive fields of study, poor infrastructure, reliance on part-time staff and a lack of research. While these might be features of PHEIs at their formative stage or of a specific category of PHEIs identified as 'demand absorbing' or 'non-elite', such descriptions do not capture the variations in this sector across the world.

Another issue that fuels these tendencies is attempts to understand PHEIs using public institutions as a benchmark in spite of the fact that PHEIs have different modes of operation and institutional structures (Slantcheva, 2002; Levy, 2002, 2009). A more reasonable approach would 
be to allow both types of institutions to fulfill their distinctive roles on the basis of their relative strengths. For instance, in Latin America, private and public institutions provide both elite and mass higher education but to different degrees (Schwartzman, 2002). India relies on public universities for research and development and uses PHEIs to meet expanding social demand for higher education through the provision of market-friendly programmes (Varghese, 20I2).

An additional source of misrepresentation of the private sector is its profit motive; with much of the literature suggesting that education and profit are incompatible (cf. Schwartzman, 2002). A major argument against 'education for economic gain' has been that the primary goal of education can easily be subverted when the objective is to make money. However, proponents of education as business argue that a profit motive is not necessarily negative as long as the institution delivers quality education (Bernasconi, 2013).

Furthermore, not-for-profit institutions are not entirely devoid of the profit motive. In South Africa, religious not-for-profit institutions exhibit such motives both in terms of their programme focus and their tuition fees (Mabizela, 2006). In Nigeria, religious educational institutions that claim an evangelical motive do not rule out the possibility of making profit (Ajayi, 2006). Private institutions owned by corporate bodies also claim to be motivated by the need to develop their clients' professional competence, but their purpose is essentially profit-making (ibid). In Ghana and Nigeria, non-profit institutions charge higher fees than public institutions (Effah, 2006; Ajayi, 2006). In Kenya, little distinction can be made between notfor-profit and for-profit institutions (Oanda, Chege, and Wesonga, 2008).

In similar vein, privatisation, which is another issue that has been used to critique PHEIs, has become a common feature of the public higher education sector in developed and developing countries. Thus, discouraging providers that seek to offer higher education in return for profit could be a misguided strategy as this criterion should not be the decisive factor in judging their educational quality (Kinser, 20I3). A wiser route would be to create mechanisms to ensure that quality is not compromised for the sake of profit. Emphasising the need for the private sector to be more responsive to societal needs and concerns would be a more viable strategy than withering away for-profit institutions which continue to mushroom. Governments should thus craft a regulatory system that balances the need to protect the public with encouraging private providers to invest in the country's education system (Bjarnason et al., 2009).

Finally, governments and the public should focus on the positive features of the PHE sector. This would inform policy on the future direction of this sector. 


\section{Emerging Trends in Africa's Private Higher Education Landscape}

While Africa was late in experiencing expansion of PHE, the continent shares most of the typical features associated with this sector. Its experiences also expose the futility of static generalisations about this sector. This section identifies key themes and examples from different countries to reveal trends as well as peculiarities that Africa shares with the rest of the world.

\section{Increased Access}

In general, PHEIs have been a valuable addition to the African higher education landscape by extending access and offering alternatives to the public sector. Many countries would have found it difficult to respond to ever growing demand for higher education without the involvement of PHEIs. PHEIs have complemented public institutions by running their programmes as affiliates (Mabizela, 2006; Levy, 2013) and by enabling access for students who could not obtain places at under-resourced public higher education institutions. For instance, from I978/79 to I999/2000, Nigerian public universities were only able to admit 25 percent of applicants (Akpotu and Akpochafo, 2009). The percentage of applicants admitted to Ghanaian universities between $1996 / 97$ and 2003/04 ranged from 25-40 percent (Effah, 2006) and in Zimbabwe only 36 percent of applicants secured a place for undergraduate studies from I990- I994. Between 2010 and 20II, about 46,000 and 59,000 qualified Kenyan applicants were turned down, respectively, due to lack of space at public universities (Wameru, 2013).

PHEIs not only assist governments by accommodating students who, as tax payers, should have the same opportunities as their compatriots in public universities but in some countries have managed to create additional opportunities for what Teixeira and Amoral (200I) call 'nontraditional students'. Students from under-represented groups such as females and adults have been the major beneficiaries. PHEIs in Tanzania have opened the doors of higher education to female students unable to meet the admission requirements of public universities. In Uganda, they enroll the same percentage of female students (around 40-42 percent) as public universities (Tumwesigye, 2006). Female students make up 55 percent of the student body in PHEIs in Kenya, while in the public sector the figure is 32 percent (Abagi, 2006). Similarly, in Ethiopia, Senegal and Zimbabwe, more than 50 percent of students that attend PHEIs are female with the figures for the public sector being much lower (Ndaiye, 2006; Chivore, 2006; Tamrat, 2008). Nigerian private institutions are dominated by female students who choose them over public institutions due to their safety, proximity, programme choice and better discipline (Wesonga et al., 2007; Omuta, 2010). 
Contrary to general expectations, PHEIs also broaden access to students located outside major cities and capitals. For example, Ethiopian PHEIs have many more distance education centres than the public sector (Tamrat, 2008). In Tanzania, where public sector higher education is concentrated in the eastern region, PHEIs have opened branches in the northern, western, and southern regions (Tumwesigye, 2006).

The capacity problems confronting public higher education in Africa have driven many students out of their country in search of education opportunities. The large number of Kenyan and Nigerian students studying abroad is partly attributed to this issue. Despite the protracted process involved in obtaining a visa, the United Kingdom draws the fifth largest population of its foreign students from Nigeria (Akpotu and Akpochafo, 2009). African PHEIs have seized this opportunity and have started competing with foreign destinations for African students. Students from Nigeria now make up around 60 percent of the student body at some private universities in Ghana(Oseni, 20I5).

However, PHE is not about access alone. It also offers conducive learning environments and programme diversification, enhances competition within the higher education sector, generates employment and income, engages in community activities and creates semi-elite institutions.

\section{Efficiency and Responsiveness}

Private institutions are generally considered to be more nimble than their public counterparts as a result of their internal culture and aspirations (Bjarnason et al., 2009). While public institutions are known to be rigid and bureaucratic, successful PHEIs are dynamic, efficient and flexible. Due to their need to be socially and economically successful, they minimise institutional spending, promote strategic planning and marketing, maintain contact with employers, offer superior job-placement services, student counseling, and remediation opportunities and promote increased accountability of their staff (Levy, 2003; Varghese, 2006).

Drop-out rates in African PHEIs are low and graduation rates are high not only due to the need for monetary gain but also because of student motivation and better monitoring of student progress (Kuhanga, 2006; Varghese, 2006). In some African countries, PHEIs are becoming the first choice of parents and students as they do not experience the incessant strikes that plague public institutions with negative impacts on graduation time (Eisemon, I992; Ajayi, 2006; Osokoya, 2007; Kwakwa et al., 20I2; Iruonagbe et al., 20I5). In Kenya and Ethiopia, PHEIs have also been credited with creating a conducive environment for dialogue with students and staff which has not been the case in public universities (Abagi, 2006; Tamrat, 2008). The employability of graduates from PHEIs is also said 
to be much better due to their market-driven courses and employmentoriented training (Varghese, 2006).

\section{Creating a Competitive Environment}

The entrepreneurial nature of PHEIs could infuse a competitive element in higher education. Their innovative and business orientation and the manner in which they organise themselves could be an example for public sector institutions. It has been argued that their income generation efforts and efficiency could inspire reform of the public sector (Levy, 2003). In I990, only five MBA programmes serving I,000 students were offered by public institutions in South Africa; due to competition from private institutions, within a decade the number of providers grew to 40 and the number of students to I5,000 (Fehnel, 2006). In Mozambique, the emergence of PHEIs has led the public sector to launch self-financing, fee-paying programmes, and to adopt curricular innovations, organisational changes and responsiveness to market demands (Langa and Zavale, 20I5). In Kenya PHEIs are credited with prompting public universities to produce graduates with market-oriented and scarce skills (Abagi, 2006). Kenyan public institutions are also known for moving into fields of study pioneered by PHEIs (Levy, 2003). Ethiopian pubic institutions, which introduced distance education much later than their private counterparts, emulated the most successful private providers in their catch-up strategies. The existence of the private sector can thus promote inter-sectoral competition and cooperation, rendering the entire system more efficient and responsive (Levy, 2003; Tamrat, 2008; Bjarnason et al., 2009).

\section{Contribution to Personal and Economic Development}

It is acknowledged that higher education contributes to superior employment opportunities, improved quality of life and economic growth. A single year's increase in the level of tertiary education is estimated to increase annual GDP growth in Africa by 0.39 percent and could eventually yield a I2 percent increase in GDP (The State of Higher Education in Africa, 20I5). African PHEIs have helped to reduce urban youth unemployment, created jobs within the sector, and increased government revenue in the form of tax.

PHEIs contribute to their local economies and communities in a variety of ways. In Senegal, PHE contributes nearly CFA I3 billion (US\$27.7 million) a year to the economy (University World News, 3I May 2009). By enrolling students who would have been an additional burden on the state and freeing up public sector resources, PHEIs enable governments to invest their scarce resources in other sectors and/or research, innovation and lower tiers of education. In addition to generating tax income 
for the government, the sector also enables governments to save foreign exchange. According to a conservative estimate, as much as Ni6o billion is repatriated each year from Nigeria in tuition fees for students studying outside the country (Oseni, 20I5).

Successful African PHEIs are also known for their strong commitment to community outreach programmes. This includes free professional services, contributions to charity, participation in local infrastructural projects, etc. (Wesonga et al., 2007; Omuta, 20IO). PHEIs participate in social initiatives like environmental protection, feeding the homeless, and assisting the community through capacity building, training and donations. In Ethiopia, private institutions provide annual scholarships to hundreds of poor students across the country while public universities have no such provisions (Tamrat, 2008). Teferra (2005) dubs this a 'unique scenario' of Ethiopian PHEIs, though others might view it as a simple public relations gimmick.

\section{Programme Focus of PHEls}

The programme focus of private institutions has been identified as commercial/religious and/or market-friendly. Trainees are prepared for immediate employment and/or to join a religious hierarchy (Varghese 2006). However, many African PHEIs offer diverse programmes in response to student demand, institutional motivation and regulatory requirements. For instance, Kenyan PHEIs' excessive focus on religious studies has shifted since 2000 (Abagi, 2006). The Agha Khan and Kiriri Women's University in Kenya has moved from traditional vocational subjects to nursing, medical courses and those with that focus on the longterm professional requirements of the global market (Oanda, Chege, and Wesonga, 2008). In Mozambique to percent of students enrolled in PHEIs are enrolled in fields such as Engineering and ICT, Natural Sciences and Agriculture and another 5.6 percent in Health and Life Sciences (Langa and Zavale, 20I5). A significant number of Ethiopian PHEIs provide training in medical and technological fields of study aside from business and the humanities for which they were known in the early days (Tamrat, 2008). Of IIO, 658 students enrolled in the private sector, I2.3 percent are studying Engineering and Technology, I7.3 percent Medical and Health Sciences, and 5 percent Agriculture and Health Sciences (MoE, 20I5).

\section{Emergence of 'Semi-elite' Institutions}

Although Africa is dominated by demand absorbing, small PHEIs, the gradual appearance of what might be called 'semi-elite institutions' in terms of quality and standards, research focus and overall status is an emerging trend. 
In countries such as Kenya and Nigeria, some semi-elite PHEIs have overtaken their public counterparts in terms of organisational features, rankings, meeting accreditation requirements, public ratings and facilities (Eisemon, I992; Ajayi, 2006; Ndegwa, 2008; Omuta, 20I0; Omomia et al., 20I4).

Due to the reputation they have earned overtime, demand for semi-elite private universities in some countries is so high that places are not easy to obtain. At some private universities in Kenya such as the United States International University and a private IT College in Ethiopia, students wait for months before they are granted admission (Farag, 2000; Teferra, 2005). The high quality courses offered by some PHEIs are achieved through links with reputable foreign institutions dictated by institutional choice or accreditation requirements as in the case of Ghana (Effah, 2006). The well-equipped Institut International de Management in Benin has strong affiliations with well-known institutions in Europe and America and attracts many local and foreign students (Fatunde, 2009). The American University of Cairo is highly regarded in Egypt as an elite national institution (Farag, 2000), while the Akrofi-Christaller Memorial Center in Ghana is popular for its extensive focus on research and applied methodology (Effah, 2006).

\section{Challenges Confronting the Private Higher Education Sector in Africa}

Notwithstanding the positive features of African PHEIs discussed above, successful PHEIs are limited in terms of scope, size and pace of growth. This is partly due to the significant bottlenecks they experience. Unlike public institutions, retaining credibility, and sustaining growth in the required direction is an uphill struggle for many PHEIs. It is important to understand these challenges if the sector is to become more responsive.

\section{Perceptions and Legitimacy}

Recognition and further proliferation of PHEIs in Africa hinges heavily on their reputation. Enhanced reputation would promote acceptance and trust and pave the way for the further growth of the private sector. Conversely, low levels of legitimacy could lead to its extinction. The major types of legitimacy that affect perceptions of PHEIs are legal legitimacy (legal recognition of this sector); market legitimacy (the level of acceptance PHE enjoys among students, graduates and employers); and professional legitimacy (the academic community's perceptions of PHEIs (Nicholascu, 2005; Slantcheva and Levy, 2007).

PHEIs in Africa continue to face legitimacy challenges due to the sector's newness, the negative effects of its purported profit motive, public policy on private higher education, and the individual behavior of private providers. 
In countries with little or no experience of PHEIs, their emergence could be marred by suspicion and negatively affected by assumed institutional roles and practices (Levy, I998, 2002). On the other hand, in countries with plural and differentiated institutional forms and missions, they might be more easily accepted, as they could be regarded as "the natural extension of the system's dynamics" (Levy, 2002, p. II). Hence the tendency to judge reality against the ideals of higher education in general could affect the manner in which the PHE sector is viewed (Levy, I998).

Often associated with business, the very idea of private can be regarded as suspect and as an intrusion in higher education (Levy, 2005). Cognizant of this, institutions and governments sometimes purposely avoid the use of the term 'private'. For instance, PHEIs in Poland prefer to be known as 'nonpublic' (Levy, 2005) while in Russia they are referred to as 'nonstate institutions' in legal documents and public discourse, signifying the state's separation from the private sector (Suspitsin, 2003). In such settings, public sector wariness is common and, whether accurate or not, allegations relating to low academic quality and hyper commercialism of the sector could be easily accepted (Kinser, 20I3).

In many African countries, the public norm with regard to education has been linked with secularism based on serving broad national public interests (Slantcheva, 2005). This makes PHEIs' profit motive difficult to accept. Since the charitable purpose of education has historically been supported by the state in the public sector and by religious organisations in the private sphere, the emergence of PHEIs that are neither state-supported nor affiliated to a faith has been cause for concern (Kinser, 2013). Perceptions of PHEIs and their legitimacy could also be affected by the public policy operating in a country which could be either prohibitive or supportive of the growth of PHE.

The problem of gaining legitimacy could be further compounded by the excessive profit motive, myopic vision and illegal behaviour of rogue private providers (Tizazu and Tamrat, 20II). PHEIs have a significant burden (perhaps much greater than their public counterparts) of addressing the concerns of students, parents, the government and other stakeholders in maintaining their quality and integrity (Teferra, 2005). Institutional practices positively or negatively affect the social and academic legitimacy of such institutions (Nicholescu, 2007). Giesecke notes that,

Establishment of an aura of legitimacy through demonstrations of both effectiveness and viability ... can and should lead to greater public recognition that the outcomes and institutional products of the private sector are essential and necessary components of higher education offerings in a given country's marketplace of universities and postsecondary educational entities (2006, p. 3). 


\section{Funding}

The major sources of funding for African PHEIs are tuition fees, subsidies from sponsoring organisations, donations, gifts and endowments (Thaver, 2003; Abagi, 2006). Self-financing is not without its challenges. Reliance on student fees not only jeopardizes the very existence of the sector but can favour investment in teaching rather than research that may be regarded as a luxury. This cannot be addressed without direct or indirect government support. In general, PHE in Africa receives limited assistance that would allow it to diversify its funding strategy and ensure its sustainability. As a corollary, PHEIs' resource limitations could result in inadequate infrastructure and facilities that could pose serious impediments to their operations.

\section{Regulatory Issues}

PHE can largely fall outside higher education policy (Levy, 2002). However, legislative frameworks could play a key role in strengthening this sector. Governments should create frameworks for PHE (Geiger I987), especially in Africa where they have the upper hand in determining the direction of a particular sector.

Experiences in countries like Nigeria, Uganda, Cameroon, Mozambique, Zimbabwe and Ethiopia exemplify the potential role of legislation in encouraging the growth of PHE (Varghese, 2006; Osokoya, 2007; Tamrat, 2008). Regulatory frameworks can enhance the development of appropriate management structures, institutional policies and procedures, institutional documentation, quality assurance systems and procedures and business decisions that would promote the recognition that PHEIs seek from the government and the public at large (Tamrat, 2008; Ellis and Steyn, 20I4).They would also protect the sector from the negative effects of rogue providers.

Another crucial factor is the level of support institutions receive from the government. Jamshidi et al. (20I2) contend that the public nature of PHE must be acknowledged at the start of any discussion on the sector. Mabizela (2006) adds that private institutions promote national growth through human resource development and should thus be supported by means of access to funds and land, favourable taxation measures and investment incentives, and staff development opportunities (Tamrat, 2008). However, support has been limited to subsidies, scholarships and financial aid provided to students in countries like Liberia, Togo and Mozambique (Chilundo, 2003; Edee, 2003; Seyon, 2003). Where support policies are in place, implementation may sometimes lag behind. For example, Ethiopia has adopted legislation on government support for the private sector but action has not been forthcoming (Tamrat, 2008). 
While lax government regulation might result in lawlessness, too stringent an approach could strangle the private sector. In this regard, the private sector might be adversely affected by 'state incapacity', defined by lengthy and bureaucratic government procedures and/or government's inability to enact laws, or 'state obtrusion' which refers to undue government interference (Galbraith, 2003). The government's stance in terms of leveling the playing field for private and public providers of higher education is another important issue (Levy, 2005). The challenges in many parts of Africa include prohibitive regulations, constantly changing requirements, uncertainty about procedures, delays in accreditating PHEIs, government's double standards in accreditation of private and public universities, and limited capacity to enforce rules and regulations (Fehnel, 2006; Tamrat, 2008; Tizazu and Tamrat,20II).

In Africa, it would seem that the PHE sector is subjected to overregulation compared to other businesses (Ellis and Steyn, 20I4). For-profit institutions and foreign providers seem to be the most common targets. In some contexts, governments impose rules based on the requirements set for the public sector or adopt tougher regulations that the private sector might not be able to comply with. There are also times when governments are caught by surprise and act on an ad hoc basis, with a tendency to fight fires as they flare up in a way that may violate their own policies and plans (Levy, 2002; Bjarnason et al., 2009).

The African continent has abundant experience of the adverse effects of highly prescriptive regulations and abrupt measures by governments that have led to significant decline in PHEIs' participation. The 26 private universities in existence in Nigeria in 1983 were all closed during General Buhari's military rule and it was eight years before they were allowed to operate again. The South African government's decision to place a moratorium on private-public partnerships between institutions resulted in a significant reduction in the number of institutions that were operating in the I990s (Fehnel, 2006). The Ethiopian government's decision to impose a moratorium on PHEIs offering fields of study such as teacher education and law in 2010 still has lingering effects in this sector.

\section{Conclusion}

In the past three decades, PHEIs have become a permanent feature of Africa's educational milieu. They have proved strong allies to African governments in responding to differentiated demand for higher education and training. Over time, it has been acknowledged that they have a positive role to play and that they complement the public education system. This has led to some governments developing fruitful relationships with the sector (Maweru, 20I3). 
Global demand for higher education is expected to increase from 97 million students in 2000 to over 262 million by 2025 . In developing economies, this means that demand will exceed supply by 20 to 50 percent (Bjarnason et al., 2009). It is clear that providing higher education only through public means will be "too large and complex for any government to meet adequately" (Shaikh et al., 20I4). Africa cannot afford to undermine or severely restrict the growth of the private sector at a time when public institutions have neither the capacity nor the means to meet demand for higher education. Rather, efforts should be directed to strengthening the private sector so that it can complement public efforts.

Persistent misunderstanding and simplification of the role of PHEIs call for fundamental change in mindset. Traditional arguments against these institutions triggered by the opportunistic behaviour of rogue providers are no longer tenable. Nor are the stereotyped characterisations that have persisted over a number of decades. As Schwartzman (2002, p. 6) notes, "If higher education [including PHE] is to play a role in the construction of a new social order, this will be more related to concrete results...than because of the ideological and political discourse developed and put forward by leaders and participants".

In conclusion, as major actors in higher education, PHEIs should continue to take responsibility for creating a viable sector that is viewed with confidence and certainty rather than suspicion and mistrust. However, mainstream higher institutions and pertinent entities should also play their part. Governments, researchers and stakeholders alike should address the current challenges by capitalising on positive trends in the interests of nurturing a vibrant PHE sector that not only responds to institutional and national concerns but also to the continental quest for economic development through developing human capital.

\section{References}

Abagi, O. (2006). Private Higher Education in Kenya. In Teferra, D. and Altbach, P.G. (eds)(2003). African Higher Education: An International Reference Handbook. Bloomington:Indiana University Press.Africa America Institute(AAI). (n.d.). State of Education in Africa Report 20I5. Prepared for Second Annual State of Education in Africa conference in Lagos, Nigeria.

Ajayi, T. (2006). Private Higher education in Nigeria. In Varghese, N.V. (ed) (2006). Growth and Expansion of Private Higher Education in Africa. Paris: UNESCO/IIEP.

Akpotu, N. E. and Akpochafo, W.P. (2009). An Analysis of Factors Influencing the Upsurge of Private Universities in Nigeria. Journal of Social Science I8 (I). 
Altbach, P.G. (2005). The Private Higher Education Revolution: An Introduction. In Altbach and D. Levy (Eds.). (2005). Private Higher Education: A Global Revolution. Rotterdam: Sense Publishers.

Altbach, P.G. (I999). (ed). Private Prometheus: Private Higher Education and Development in the $21^{\text {st }}$ Century. Boston: Boston College Center for International Higher Education and Greenwood Publishing Co.

Altbach, P. G. (I998). Private Higher Education: Themes and Variations in Comparative Perspective. International Higher Education Winter.

Amponsah, E.B. and Onuoha, L.N. (2013). The Performance and Challenges of Private Universities in Ghana and Nigeria. International Journal of Business and Social Science 4 (5).

Atchoarena, D and P. Esquieu (2002). Private Technical and Vocational Education in Sub-Saharan Africa. Paris: UNESCO.

Banya, K. (200I). Sub- Saharan Africa: the State of Public Higher Education and the Emergence of Private Sector Universities. WENR World Educations News and Reviews Newsletter Nov I.

Barsoum, G. (20I4). The Challenges of Private Higher Education in Egypt. Economic Research Forum Working Paper 833.

Bernasconi, A. (2003). Private Higher Education with an Academic Focus: Chile's New Exceptionalism. International Higher Education, Summer.

Bernasconi, A. (2004). External Affiliations and Diversity: Chile's Private Universities in International Perspective" PROPHE Working Paper No 4 .

Bernasconi, A. (2013). The Profit Motive in Higher Education. International Higher Education, I7.

Chilundo, A. (2003). Mozambique, In Teferra, D. and Altbach, P.G. (eds) (2003). African Higher Education: An International Reference Handbook. Bloomington: Indiana University Press, pp. 462-475.

Chivore, B.R.S. (2006) Private Higher Education in Zimbabwe. In Varghese, N.V. (ed) (2006) Growth and Expansion of Private Higher Education in Africa. Paris: UNESCO/IIEP.

Edee, A.B.K.M. (2003) Togo.In Teferra, D. and Altbach, P.G. (eds) (2003). African Higher Education: An International Reference Handbook. Bloomington: Indiana University Press pp. 595-600.

Effah, P. (2006). Private Higher Education in Ghana. In Varghese, N.V. (ed) (2006) Growth and Expansion of Private Higher Education in Africa. Paris: UNESCO/IIEP.Eisemon I992.

Eisemon, T.O. (I992). Private Initiatives in Higher Education in Kenya. Higher Education 24, I57- I75.

Ellis, M.E. and Steyn, G.M.(20I4). Managers' Perceptions of Regulatory Legislation of Private Higher Education in South Africa. International Journal of Educational Science 6 (3). 
Farag, I. (2000). Higher Education in Egypt: The Realpolitik of Privatization. International Higher Education, Winter.

Fatunde, T (2009). Benin: Steady Growth in Private Tertiary Institutions. University World News, Nov Issue no 4I.

Federal Ministry of Education (FMoE). (20I5). Education Sector Development Programme V. Addis Ababa: FMoE.

Fehnel, R. (2006). Private Higher Education. In Cloete, N., Maassen, P., Fehnel, R., Moja, T., Helene Perold, H., and Gibbon, T. (eds) Transformation in Higher Education: Global Pressures and Local Realities in South Africa, Vol Io, pp. 227- 243.

Froneman. L. (2002). Private Higher Educational Institutions in a Changing South African Environment. Acta Commercii, 2.

Galbraith, K. (2003). Towards Quality Private Higher Education in Central and Eastern Europe. Higher Education in Europe 28(4), 539-558.

Geiger, R. L. (1987). Patterns of Public-Private Differentiation in Higher Education: An International Comparison. In Program on Non- Profit Organizations, Institution for Social and Policy Studies, Yale University.

Giesecke, H. (2006). Legitimacy Seeking among New Private Institutions of Higher Education. Higher Education in Europe3I (I).

Iruonagbe, C.T., Imhonopi, D., and Egharevba, M.E. (20I5). Higher Education in Nigeria and the Emergence of Private Universities. International Journal of Education and Research 3 (2).

James, E. (I989). Differences between Public and Private Higher Education: An International Perspective. PONPO Working Paper No I4I and ISPS Working Paper No 2I4I, Yale University.

Jamshidi, L., Arasteh, H., Naveh Ebrahim, A., Zeinabadi, H., and Rasmussen, P. D. (20I2). Developmental Patterns of Privatization in Higher Education: A Comparative Study. Higher Education 64, 789-803.

Kent, R. (I995). Two Positions in the International Debate about Higher Education: the World Bank and UNESCO. Presented at the Meeting of the Latin American Studies Association, Washington, Sept. 28-30, I995.

Kinser, K. (2013). The Quality- Profit Assumption. International Higher Education $7 \mathrm{I}$.

Kodin, E. (I996) Problems of Private Higher Education in Russia.International Higher Education November 1996.

Kruss, G. (2003). More, Better, Different? Understanding Private Higher Education in South Africa. Education and Skills Development (ESD). HSRC

Kuhanga, N.A. (2006). Private Higher Education in Tanzania. In Varghese, N.V. (ed) (2006) Growth and Expansion of Private Higher Education in 
Africa. Paris: UNESCO/IIEP.

Kwakwa. P.A, Arthur, E. and Obeng, S. (20I2). Demand for Private higher Education in Ghana: the Case of the Presbyterian University College Ghana, Akuapem Campus. International Journal of Management Research and Review 2 (5).

Langa, P.V. and Zavale, N.C. (20I5). Private Higher Education in Mozambique: An Overview of a Growing Subsystem. Working Papers in Higher Education Studies, I (20), 89-109.

Lee, M.N. (2003). International Linkages in Malaysian Private Higher Education. International Higher Education, Winter.

Levy, D. (2013). Squeezing the Non- profit Sector. International Higher Education, $7 \mathrm{I}$.

Levy, D. C. (2005). Private Higher Education's Surprise Roles. In P. G. Altbach and D. Levy. The Private Higher Education Revolution: An Introduction. In Private Higher Education: A Global Revolution. Rotterdam: Sense Publishers.

Levy, D. C. (2009). Growth and Typology. In S. Bjarnason, K. M. Cheng, J. Fielden, M.J. Lemaitre, D.Levy and N. V. Varghese (Eds) A New Dynamic: Private Higher Education. Paris: UNESCO.

Levy, D.C. (2002). Unanticipated Development: Perspectives on Private Higher Education's Emerging Role. PROPHE Working Paper No I.

Levy, D.C. (2003). Expanding Higher Education Capacity through Private Growth: Contributions and Challenges. In The Observatory on Borderless Education Report, January.

Levy, D.C. (2003). Profits and Practicality: How South Africa Epitomizes the Global Surge in Commercial Private Higher Education. PROPHE Working Paper Series No 2.

Levy, D.C. (2005). Analyzing a Private Revolution: The Work of PROPHE. International Higher Education, Spring.

Levy, D.C. (2006). The Unanticipated Explosion: Private Higher Education's Global Surge. Comparative Education Review 50(2), 2I7-240.

Mabizela, M. (2006). Recounting the State of Private Higher Education in South Africa. In Varghese, N.V. (ed) (2006). Growth and Expansion of Private Higher Education in Africa. Paris: UNESCO/IIEP.

Maldonado- Maldondo, A., Cao, Y., Altbach, P.G., Levy, D.C., and Zhu, H. (2004). Private Higher Education: An International Bibliography. Massachusetts: Center for International Higher Education, Lynch school of Education, Boston College.

Maweru, S.N.(2013). The Role of Private Universities in Meeting Demand for Higher Education in Kenya. International Journal of Education and Research I (12).

Mwiria, K., Nge'the, N., Ngome, C., Ouma-Odero, D., Mawire, V., and 
Wesonga, D. (2007). Public and Private Universities in Kenya: New Challenges, Issues and achievements. Cumbria: Long House Publishing Services.

Ndegwa, S. (2008). Kenya: Private University Growth a Mixed Blessing. University World News, Africa Edition. I3 April, Issue No23

Ndiaye, A.L. (2006). Birth and Development of Private Higher Education in Senegal. In Teferra, D. and Altbach, P.G. (eds)(2003). African Higher Education: An International Reference Handbook. Bloomington: Indiana University Press.

Nicholascu. L. (2007). Institutional efforts for Legislative Recognition and Market Acceptance: Romanian Private Higher Education. In Slantcheva, S. and Levy. D.C.(eds). (2007).Private Higher Education in Post-communist Europe: In Search of Legitimacy. Hampshire: Palgrave Macmillan.

Nicolascu, L. (2005). Private versus Public in Romania: Consequences for the Market. International Higher Education Spring.

Oanda, I.O. Chege, F.N. and Wesonga, D.M. (2008). Privatization and Private Higher Education in Kenya: Implications for Access, Equity and Knowledge Production. CODESIRA.

Obasi, I. N. (2006). New Private Universities in Nigeria. International Higher Education, 45 (Fall).

Ochwa-Echel, J. (2016). Private Universities in Uganda: Issues and Challenges. International Journal of Education and Social Science 3 (3).

Odon, A. (2015). Private Colleges can Benefit Africa's Students. Mail and Guardian, July I7.

OECD. (20I7). State of Education in Africa 20I5: Executive Summary. The Africa-America Institute. www.aaionline.org/wp- content/ uploads/20I5/o9/AAI- SOE- report- 20I5- final.pdf

Olayia, T.A. (20I5). Expanding Private Higher Educational Institutions in Africa: Implications for Good Governance. British Journal of Education3(2).

Omomia, O.A., Omomia, T.A., and Babalola, J.A. (20I4). The History of Private Sector Participation in University Education in Nigeria (I9982012). Research on Humanities and Social Sciences 4 (I8).

Omuta, G. (2010). The Place of Private Participation in Higher Education: A Periscope on Private Universities in Nigeria, CPED Monograph Series No2. Benin City: Center for Population and Environmental Development.

Oseni, M. (2015). Effectiveness and Desirability of Private Higher Education in Nigeria. Journal of Educational and Social Research 5 (I).

Osokoya, I.O. (2007). Privatization of University Education in Africa: Lessons from the Theories and Practices of the United States of 
America and Japan. International Journal of African and African American Studies, 6 (2).

Sayed, Y. (200I). The Growth of the Private Higher Education Sector in South Africa: Governance and Regulation Challenges. Paper Read at 'Globalization and Higher Education: Views from the South Conference' March, 200 I.

Schwartzman, S. (2002). Public and Private Higher Education in Comparative Perspective. A Revised Version of the Keynote Presentation Prepared for the Colloquium on Understanding Private Higher Education in South Africa", Human Sciences Research Council, Johannesburg, April 9-Io.

Sehoole, C. 20I2. A Decade of Regulating Private Higher Education in South Africa. International Higher Education, 66 (Winter).

Seyon, P.L.N.(2003) Liberia. In Teferra, D. and Altbach, P.G. (eds). (2003). African Higher Education: An International Reference Handbook. Bloomington: Indiana University Press pp. 38I-390.

Shaikh, A., Karodia, A., David, J. and Soni, D. (20I4). Private Providers Widen Access to Higher Education: A Fertile Idea whose Time has Come. Press Release, 29 January.

Slantcheva, S. (200I). Private Higher Education in Bulgaria and Its Role in Providing Alternative Educational Opportunities 23rd EAIR Forum, 9-I2 200I, Porto, Portugal.

Slantcheva, S. (2002). The Private Universities of Bulgaria. In Altbach, PG and Levy, DC (eds) Private Higher Education: A Global Revolution.

Slantcheva, S. and Levy. D.C. (eds). (2007). Private Higher Education in Post- communist Europe: In Search of Legitimacy. Hampshire: Palgrave Macmillan.

Suspitsin, D. (2003). Russian Private Higher Education: Alliances with State-Run Organizations. International Higher Education, Fall.

Tamrat, W. (2008). The Anatomy of Private Higher Education in Ethiopia: Current Landscape, Challenges and Prospects. Addis Ababa: St. Mary's University Publications.

Teferra, D. (2005). Private Higher Education in Ethiopia: The Current Landscape. In Altbach and Levy, Private Higher Education: A Global Revolution. Rotterdam: Sense Publishers.

Teixiera, P. and Amoral, A. (200I). Private Higher Education and Diversity: An Exploratory Survey. Higher Education Quarterly, 55(4), 359-395.

Thaver, B. (2003). Private Higher Education in Africa: Six Country Case Studies. In Teferra, D. and Altbach, P.G. (eds). (2003). African Higher Education: An International Reference Handbook. Bloomington: Indiana University Press.

Tizazu, G. and Tamrat, W. (20II). The Status of Private Provision of Higher 
Education in Ethiopia. In Proceedings of the 9th National Conference on Private Higher Education Institutions (PHEIs) in Ethiopia. Addis Ababa: St. Mary's University College Press.

Tsevi, L. (20I5). Quality Assurance in Private Higher Education: The Case of Ghana. PROPHE Working Paper Series No 20.

Tumwesigye, G. (2006). Private Higher Education in Uganda. In Varghese, N.V. (ed). (2006) Growth and Expansion of Private Higher Education in Africa. Paris: UNESCO/IIEP.

University World News. (2009). 3I May, Issue No 30.

Varghese, N.V. (20I2). Private Higher Education: The Global Surge and Indian Concerns. In India Infrastructure Report $20 \mathrm{I} 2$.

Varghese, N.V. (ed). (2006). Growth and Expansion of Private Higher Education in Africa. Paris: UNESCO/IIEP.

Wameru, S.N. (20I3). The Role of Private Universities in Meeting Demand for Higher Education in Kenya. International Journal of Education and Research, I (I2).

World Bank. (2009). Accelerating Catch-up: Tertiary Education for Growth in Sub-Saharan Africa. Washington: The World Bank.

World Bank. (2009). The Evolving regulatory Context for Private higher education in emerging economies. Working Paper No I54. Washington: The World Bank. 